\title{
Penguatan nilai-nilai Pancasila pada era disrupsi di lingkungan pendidikan dasar
}

\author{
Normah ${ }^{1}$, Isna Sari Rukmana ${ }^{2}$, Putri Dinda Kemala ${ }^{3}$ \\ ${ }^{1}$ MIN 01 Indragiri Hilir, Riau, Indonesia \\ 2,3 Program Studi PPKn, Program Pascasarjana, Universitas Negeri Yogyakarta, Indonesia
}

\section{ABSTRAK}

Penguatan nilai-nilai Pancasila dalam proses pendidikan merupakan hal sangat penting untuk digali. Hal tersebut termasuk sekolah dasar sebagai penyelenggara Pendidikan. Penelitian ini didasarkan pada pentingnya penguatan nilai Pancasila pada peserta didik di era disrupsi saat ini. Tujuan penelitian ini adalah untuk mengetahui bagaimana penguatan nilai-nilai Pancasila di MIN 01 Indragiri Hilir dan untuk mengetahui kendala apa yang dihadapi untuk memperkuat nilai-nilai Pancasila di MIN 01 Indragiri Hilir. Penelitian ini menggunakan metode penelitian kualitatif, dengan teknik pengumpulan data melalui studi pustaka, observasi, wawancara, dan dokumentasi. Subjek penelitian dalam artikel ini adalah kepala sekolah, wali kelas, guru mata pelajaran, staff sekolah, dan siswa. Hasil penelitian menunjukkan bahwa penguatan nilai-nilai Pancasila dilaksanakan dengan jalur sosialisasi Pancasila melalui pengembangan sosial budaya yang dilakukan dengan melaksanakan upacara bendera, melaksanakan salat berjamaah, melaksanakan kegiatan gotong-royong, pemilihan ketua kelas, melaksanakan pembelajaran di kelas, melaksanakan kegiatan senam pagi, memperingati hari penting nasional, melaksanakan kegiatan Pramuka, dan melaksanakan kegiatan gotong-royong. Kendala yang dihadapi dalam upaya penguatan nilainilai Pancasila di MIN 01 Indragiri Hilir meliputi keterbatasan lahan, alat dan media yang terbatas, dan tenaga pendidik yang sesuai kegiatan yang dikembangkan masih kurang.

\section{ABSTRACT}

Strengthening the values of Pancasila in education process is very important to be explored, includes in elementary schools. The article base on the importance of strengthening the value of Pancasila in students in the disruption. The purpose of this study was to determine how to strengthen the values of Pancasila in MIN 01 Indragiri Hilir and to find out what obstacles were faced to strengthen the values of Pancasila in MIN 01 Indragiri Hilir. This study uses qualitative research with a literature review, observation, interviews, and documentation. The research subjects in this article are the principal, teacher, school staff, and students. The results showed the strengthening of Pancasila values was carried out through the socialization of Pancasila through the socio-cultural development by carrying out flag ceremonies, performing congregational prayers, mutual cooperation activities, selecting class leaders, learning in class, gymnastics activities, commemorating national important day, carrying out Boy Scout activities, and carrying out mutual assistance activities. Constraints faced in the effort to strengthen the values of Pancasila in MIN 01 Indragiri Hilir include limited land, limited tools and media, and educators according to the activities being developed, are still lacking.

\section{Pendahuluan}

Perkembangan pendidikan pada Revolusi Industri 4.0 saat ini ditandai dengan terjadinya Perubahan sangat signifikan pada aspek ilmu pengetahuan, teknologi, dan komunikasi dan sangat berpengaruh pada karakter manusia dan dunia kerja (Maemunah, 2018; Trisiana et al., 2019). Pada masa ini juga akan terjadi perubahan pada era sebelumnya, sehingga dampak logis yang harus dihadapi adalah perubahan dan pergeseran jenis tenaga kerja pada era sekarang dan mendatang (Suwardana, 2018). Indonesia sebagai negara berkembang yang turut berkomitmen dalam era ini juga harus mampu menyiapkan sumber daya manusia yang andal, memiliki disiplin yang bagus, 
memiliki kualitas dan kuantitas yang tinggi, hingga mampu bersaing pada era persaingan global (Subekti et al., 2018). Namun pada kenyataannya, Indonesia saat ini masih dihadapkan pada kondisi Sumber Daya Manusia (SDM) dengan angkatan kerja berkisar $58.76 \%$ yang merupakan lulusan SDSMP dan masalah ketidakcocokan mencapai $63 \%$, oleh sebab itu diperlukan suatu usaha dari sedini mungkin dalam upaya pembangunan SDM agar keterampilan dan kompetensi sumber daya manusia di Indonesia mampu bersaing (Kusdiantini, 2018; Revolusi Industri 4.0 Dan Pentingnya Pengembangan Kualitas Sumber Daya Manusia (SDM) Indonesia Halaman All - Kompasiana.Com, n.d.). Hal tersebut menunjukkan bahwa keadaan sumber daya manusia di Indonesia masih rendah dan jauh dari kata produktif. Padahal seharusnya sumber daya manusia pada era ini harus lebih mampu bersaing dan lebih baik dari sebelumnya.

Kondisi pendidikan pada era revolusi industri saat ini ibarat seperti dua sisi mata uang. Satu sisi memiliki nilai positif bagi produktivitas hasil kerja dan efisiensi proses produksi. Namun pada sisi lain, revolusi industri juga memiliki sisi negatif, diantaranya adalah kompetitif dunia kerja yang berujung banyaknya tenaga kerja tidak terpakai dan disrupsi teknologi yang harus diantisipasi oleh Indonesia (Satya, 2018). Perubahan tersebut juga berdampak pada perkembangan dunia yang masuk pada era digital yang disebut era disrupsi, sehingga semua sektor termasuk politik, ekonomi, dan pendidikan juga merasakan dampaknya (Harto, 2018). Dampak tersebut menyebabkan dunia pendidikan sebagai sarana untuk melaksanakan dan penyaluran ilmu pengetahuan secara eksplisit harus memiliki sistem yang dapat mendukung bagi terselenggaranya kegiatan tersebut. Hal tersebut dapat dilihat dari tantangan yang turut dihadapi pendidikan di Indonesia yang dituntut agar memiliki cara berpikir, cara belajar, dan cara bertindak para peserta didik yang masih terbatas. Oleh sebab itu, perlu adanya upaya dari dini yang dilakukan oleh pendidik untuk menghasilkan pendidikan yang bermutu dan berkualitas dan memperbaiki moral generasi emas di masa yang akan datang (Nursyifa, 2019).

Pengaruh teknologi dan komunikasi yang cepat pada era disrupsi ini juga berpengaruh pada Tingginya penggunaan media sosial yang digunakan oleh masyarakat (Triyanto \& Fadhilah, 2018). Hal itu ditunjukkan dengan media sosial yang sekarang semakin menjamur, sehingga menimbulkan perilaku anti sosial dan melunturkan kebiasaan-kebiasaan baik yang berakar dari nilai-nilai Pancasila di kalangan masyarakat terutama siswa (Amedie, 2015; Nasihuddin, 2016), belum lagi terjadinya ketimpangan antara sikap moral yang diharapkan ideal dengan keadaan sebenarnya mengenai keadaan sosial yang terjadi di sekolah maupun di masyarakat. Hal tersebut menandakan perlu ditingkatkannya penguatan nilai-nilai Pancasila dalam proses pendidikan yang dilakukan melalui proses kehidupan bermasyarakat, berbangsa, dan bernegara.

Banyak cara yang dapat dilakukan untuk menguatkan nilai-nilai Pancasila. Pada tataran instrumental makro, perlu adanya school-based values education dan society-based values education sebagai wadah dalam memperbaiki nilai-moral secara sistemis dan menyeluruh untuk menciptakan kondisi budaya sosial di sekolah yang sesuai dengan apa yang diharapkan (Hakam, 2011). Cara yang tepat untuk dilakukan dapat dalam mengatasi permasalahan tersebut adalah dengan penguatan, penanaman dan memberikan pengetahuan awal mengenai Pancasila sejak usia dini terutama pada umur 7-11 tahun, yaitu pada jenjang sekolah dasar dan madrasah ibtidaiah (Niron et al., 2013). Hal tersebut dikarenakan siswa SD/MI masih ada di tingkatan awal dan sangat potensial untuk menerima pemahaman mengenai nilai-nilai Pancasila sejak dini (Kus, 2015). Siswa SD/MI juga dapat dijadikan sebagai acuan dalam proses penyusunan dalam penguatan nilai-nilai pancasila, sehingga dapat mulai menggunakan aturan-aturan yang jelas dan logis yang diajarkan oleh para pendidik di sekolah dan menentukan fondasi awal untuk melangkah melanjutkan pendidikan (Mares et al., 2015). Oleh karena itu, perlu adanya upaya penguatan di sekolah dasar. Salah satunya adalah Madrasah Ibtidaiah Negeri 01 Indragiri Hilir yang menjadi sekolah agama yang berada di tengah kota Tembilahan, memiliki keunggulan dan prestasi yang cukup banyak pada bidang umum dan agama. 
Berdasarkan pemaparan tersebut, maka penelitian ini akan dilakukan di Madrasah Ibtidaiah Negeri 01 Indragiri Hilir dengan tujuan untuk mengetahui upaya-upaya yang dilakukan oleh sekolah untuk penguatan nilai-nilai Pancasila dan kendala apa saja yang dihadapi pihak sekolah dalam upaya penguatan nilai-nilai Pancasila di sekolah pada era disrupsi saat ini.

\section{Metode}

Metode penelitian yang digunakan dalam penelitian ini menggunakan pendekatan kualitatif pada salah satu Madrasah Ibtidaiah Negeri (MIN) di Kabupaten Indragiri Hilir yang beralamat di Jalan Perintis, Tembilahan Hulu, Kabupaten Indragiri Hilir, Riau yang telah menerapkan kurikulum 2013 dan lebih menekankan pada aspek penilaian dan pengembangan kognitif, afektif, dan psikologis siswa.

Penentuan informan dalam penelitian ini ditentukan lewat teknik purposive, artinya informan yang dipilih berdasarkan pada penilaian, alasan yang jelas, dan tujuan yang sudah ditentukan, misalnya orang-orang yang dianggap telah memahami situasi sosial atau masalah yang akan diteliti (Sugiyono, 2012). Oleh karena itu, narasumber pada penelitian ini adalah Kepala Sekolah MIN 01 Indragiri Hilir selaku pengawas kegiatan di sekolah. Wali Kelas I-VI MIN 01 Indragiri Hilir selaku pemegang wewenang tertinggi pada kelas dan mengetahui karakter setiap siswa di tiap kelas yang dipimpin.

Teknik pengumpulan data pada penelitian ini adalah studi kepustakaan, observasi, wawancara kepada kepala sekolah dan guru pada MIN 01 Indragiri Hilir, serta dokumentasi kegiatan. Kemudian untuk validitas data pada penelitian ini menggunakan triangulasi sumber dan triangulasi teknik. Analisis data pada penelitian ini berlangsung selama proses pengumpulan data dan setelah selesai pengumpulan data yang menggunakan teknik dari Creswell (2014) yang terdiri dari mengorganisasikan dan menyiapkan data, membaca data, proses coding atau analisis umum, proses pengategorian coding yang sudah dibuat, mendeskripsikan tema-tema kedalam penjelasan kualitatif, dan analisis akhir.

\section{Hasil dan Pembahasan}

Penguatan dan pelaksanaan sosialisasi nilai-nilai Pancasila dapat dilakukan melalui berbagai cara. Salah satunya dapat diterapkan melalui pengembangan pendidikan pembelajaran, pengembangan sosial budaya, dan pengembangan melalui kekuasaan di (Budimansyah, 2010). Penguatan nilai-nilai Pancasila di SD/MI merupakan bagian dari jalur pendidikan pembelajaran ( $p s y c o-$ pedagogial development) yang tidak terlepas dari berbagai macam kegiatan di kelas berupa pembelajaran yang menyangkut aspek Pengetahuan (kognitif), sikap (afektif), dan keterampilan (psikomotorik). Namun bukan hanya melalui pembelajaran berupa penyampaian materi dan pengetahuan di kelas, melainkan juga dapat dilakukan dengan penguatan nilai-nilai Pancasila yang memfokuskan kepada aspek sikap atau akhlak siswa menjadi lebih baik, membuat kecerdasan emosional peserta didik menjadi lebih kuat, tajam pikirannya, inderanya juga cermat, dan memiliki sikap dan martabat sesuai dengan situasi dan kondisi untuk berperilaku (Kuzhanova et al., 2017). Upaya-upaya yang dapat ditempuh dalam menguatkan nilai-nilai Pancasila di SD/MI dapat dilihat dari berbagai kegiatan-kegiatan yang dilakukan di sekolah tersebut. Kegiatan di SD/MI yang dapat mendukung untuk menguatkan nilai-nilai Pancasila dapat dijabarkan sebagai berikut.

\section{Melaksanakan Upacara Bendera}

Pelaksanaan kegiatan upacara bendera merupakan kegiatan rutin yang dilakukan pada setiap hari senin pukul 07.00 WIB. Kegiatan ini juga dilakukan dalam rangka memperingati hari-hari nasional, seperti: sumpah pemuda; 17 agustus; hari guru; hari pendidikan; hari Pramuka; dan lain sebagainya. Tujuan pelaksanaan kegiatan ini adalah untuk mencerminkan sikap persatuan dan kesatuan diantara siswa, guru, dan staf pendukung di sekolah, memupuk rasa nasionalisme dan patriotism sedini 
mungkin dikalangan siswa. melalui kegiatan rutin ini jugalah siswa dan seluruh warga di sekolah menjadi terbiasa untuk bersikap disiplin dan tepat waktu. Hal tersebut dikarenakan upacara yang selalu dilakukan oleh pihak sekolah selalu diadakan pada pagi hari, pukul 07.00 WIB, sehingga siswa dan guru-guru banyak yang terlambat dan menunggu di luar pagar.

Maka dari itu, melaksanakan upacara ini turut mendukung perubahan warga sekolah menjadi lebih baik. Kegiatan upacara bendera ini diikuti oleh siswa kelas I-IV yang memang masuk pada pagi hari dan juga seluruh guru dan staff sekolah. Petugas upacara secara bergiliran dilaksanakan oleh kelas yang berbeda, mulai dari kelas III sampai kelas VI akan bergiliran setiap minggu bertugas sebagai pemimpin upacara, membacakan teks pembukaan Undang-Undang Dasar 1945, MC, dan doa. Petugas yang menyampaikan amanat pada pagi hari pun juga berbeda-beda. Hal ini bertujuan untuk menghindari rasa bosan dan monoton bila hanya kepala sekolah saja yang berbicara setiap minggu nya.

\section{Melaksanakan Salat Jamaah}

Manusia selalu berusaha untuk menirukan dunia yang suci ke dunia nyata yang fana seperti saat ini dengan berusaha menerima kebaikan Tuhan melalui kegiatan agama (Puspitasari et al., 2012). Oleh karena itu, setiap wilayah secara material terkait dengan berbagai hal-hal immaterial di dunia (Goh \& van der Veer, 2016). Salah satunya adalah wilayah SD/MI pada penelitian ini terdiri dari siswa, guru, dan pengurus yang menganut agama Islam. Kegiatan religius dan berbau agama yang selalu diterapkan oleh pihak sekolah adalah melaksanakan salat jamaah Zuhur dan Asar. Kegiatan ini dilakukan saat istirahat pertama bagi siswa kelas II, III, dan IV tepat dengan waktu salat Zuhur. Kegiatan salat jamaah ini dilakukan lima hari dari enam hari pertemuan sekolah yakni Senin, Selasa, Rabu, Kamis, dan Sabtu. Pada kegiatan ini, kepala sekolah ataupun guru laki-laki yang akan memimpin sebagai imam.

Kegiatan mulai dari kegiatan wudu di kamar mandi ataupun tempat wudu, guru lain, baik guru laki-laki maupun guru perempuan akan mengawasi setiap kegiatan siswa agar tidak membuat keributan dan mengganggu aktivitas orang lain yang tengah beribadah di area musala. Karena pada dasarnya, hal ini penting untuk dilaksanakan untuk menunjang pelaksanaan pembelajaran yang telah diajarkan di kelas berupa materi mengenai tata cara beribadah menghadap Tuhan dalam membelajarkan agama dan perwakilan kelompok sosial yang dipercayai mampu mengajarkan hal tersebut (Necula, 2014)

Kebiasaan melaksanakan salat berjamaah ini juga dilakukan agar siswa dapat bersosialisasi dengan siswa dari kelas yang lain. Selain itu, melalui kegiatan ini juga dapat memupuk rasa religius siswa akan agama yang dianut, mendisiplinkan dan melatih siswa untuk salat tepat waktu. Karena pada dasarnya, upaya yang niscaya dapat dilakukan untuk menguatkan nilai ketuhanan di SD/MI tersebut dapat diterapkan melalui pengajaran, peneladanan, pelatihan, pembinaan disiplin dan kontrol diri, dan memberi contoh yang baik dalam menjalankan ajaran agama yang dianut untuk membantu siswa dalam membiasakan diri dalam bersikap disiplin dan religius pada setiap kegiatan di lingkungan sekolah dan masyarakat.

\section{Melaksanakan Kegiatan Gotong Royong}

Kegiatan gotong royong merupakan kebiasaan yang telah berkembang dalam kehidupan sosial masyarakat Indonesia sejak dulu dan telah menjadi salah satu warisan budaya yang tetap ada hingga kini. Gotong royong pada dasarnya merupakan bentuk kerja sama yang dilakukan oleh sekelompok orang, masyarakat untuk mencapai suatu hasil positif dari kegiatan yang telah dilakukan tersebut. Kegiatan gotong royong muncul atas kesadaran diri dan semangat masing-masing individu untuk secara bersama-sama mengerjakan, menanggung akibat dari suatu karya, terutama yang benar-benar dilakukan secara bersama-sama, tanpa memikirkan dan mengutamakan 
keuntungan bagi dirinya sendiri, melainkan selalu menjunjung tinggi kebahagiaan bersama (Effendi, 2013).

Kegiatan gotong royong di sekolah biasanya dilaksanakan pada hari Jumat dan hari-hari tertentu setelah ujian semester dilakukan. Kegiatan ini melibatkan seluruh elemen sekolah. Memang pada hari biasanya, yang memelihara kebun, menyiram tanaman, dan menjaga keindahan sekolah adalah ibu Epi, namun ada beberapa saat rumput-rumput di sekitaran sekolah menjadi sangat rindang, kacakaca di setiap kelas tebal oleh debu, dan warna cat pada dinding sekolah sudah mulai meluntur, oleh sebab itu, diperlukan seluruh elemen sekolah untuk saling bekerja sama bergotong royong dalam menjaga keasrian, membersihkan, dan merapikan semuanya secara bersama-sama agar lingkungan sekolah yang bersih, indah untuk dipandang, dan nyaman untuk ditempati. Karena pada dasarnya, lingkungan yang memiliki pemandangan menarik merupakan sumber inspirasi bagi siswa, guru, karyawan sekolah dan orang tua (Ali et al., 2015).

Selain untuk menjaga dan melestarikan lingkungan, kegiatan ini juga bertujuan untuk menguatkan nilai persatuan dan kesatuan antara siswa, guru, dan staff di sekolah. Melalui kegiatan gotong royong tersebut semua elemen sekolah bersatu padu untuk membersihkan lingkungan sekolah secara bersama-sama.

\section{Pemilihan Ketua Kelas}

Proses pemilihan ketua kelas menggunakan voting pada kelas I-III, sedangkan pada kelas IV-VI menggunakan musyawarah mufakat dengan bimbingan dan arahan dari wali kelas masing-masing. Voting yang dilakukan pada kelas I dan III dilakukan karena siswa belum mampu untuk memutuskan secara rasional, para siswa hanya menunjuk temannya untuk menjadi ketua kelas. Sedangkan pada kelas IV-VI menggunakan metode musyawarah dan mufakat karena siswa pada tingkatan tersebut sudah mulai mampu memutuskan siapa yang berhak menjadi ketua kelas sesuai kriteria dan bukan asal tunjuk. Ditambah lagi, musyawarah dapat dikendalikan secara sadar (Pachur \& Spaar, 2015). Artinya siswa yang diawasi oleh guru ataupun wali kelas dapat secara bersama-sama memutuskan yang terbaik.

Kegiatan yang dilakukan tersebut mencerminkan adanya musyawarah untuk mencapai suatu hasil yang baik. Kegiatan ini juga dilakukan supaya para guru dan wali kelas dapat memberdayakan siswa agar turut berpartisipasi dalam memutuskan suatu hal (Vassil \& Weber, 2011). Kegiatan pemilihan ketua kelas ini dilaksanakan pada setiap awal semester ganjil dan genap. Kegiatan ini bertujuan untuk meningkatkan kesiapan siswa untuk menjadi pemimpin, melatih siswa untuk menanamkan nilai demokrasi di sekolah, melatih siswa untuk memiliki sikap percaya diri dalam menyampaikan pilihannya, karena pada dasarnya seorang ketua kelas ataupun wakil ketua kelas tidak dipilih murni oleh guru melainkan juga mengikutsertakan pilihan dari para siswa/I di kelas tersebut. Pola ini melatih siswa untuk mampu bersaing tidak hanya di level lokal, namun berkembang pada level lebih tinggi ketika dewasa kelak (Arpannudin \& Aulia, 2020).

Apabila siswa tidak diikutsertakan dalam praktik pemilihan ketua kelas, maka dapat dikatakan bahwa proses dan praktik dari demokrasi tidak berhasil. Jika hal tersebut terjadi, maka yang akan terjadi adalah proses pendewasaan dalam demokrasi yang tidak berhasil dan kacau pada tingkat selanjutnya (Markopoulos \& Vanharanta, 2015). Maka dari itu, perlu adanya kegiatan pemilihan ketua kelas dengan tujuan untuk melatih kesiapan peserta didik untuk menjadi seorang pemimpin, mengikutsertakan siswanya dalam pemilihan demokrasi, menyampaikan pendapat dan pilihan yang merupakan bagian upaya meminimalisasi terjadinya kekacauan, kebodohan, dan tindak anarki dari gagalnya proses demokrasi di SD/MI tersebut. 


\section{Mengadakan Kegiatan Pelatihan Pramuka}

Kegiatan pelatihan pramuka dilakukan setiap pagi minggu. Hal ini dilakukan untuk melatih sikap kepemimpinan dan latihan baris-berbaris yang rapi dan teratur. Kegiatan ini dilakukan selama 1-2 jam yang diisi dengan materi dan praktik kepramukaan. Bisa berupa latihan baris-berbaris di lapangan, ataupun latihan tali-menali yang baik, ataupun menyanyikan lagu-lagu mengenai semangat kepramukaan. Siswa yang mengikuti kegiatan ini adalah siswa kelas I-V. Tujuan lain dilaksanakannya kegiatan ini adalah untuk memupuk rasa persatuan dan kesatuan diantara para peserta didik, memupuk rasa percaya diri dan meningkatkan keterampilan siswa dalam sikap dan ketahanan mental untuk mengikuti kemah di luar sekolah nantinya.

Kegiatan pelatihan gerakan pramuka merupakan bentuk dari penyelenggaraan pendidikan non formal yang ada di luar sekolah. Melalui kegiatan ini juga, siswa dapat memperoleh manfaat yang sangat baik sekali mengenai kesadaran bela Negara, memiliki sikap, tekad, dan perilaku nasionalisme, memiliki sikap kecintaan terhadap Negara Kesatuan Republik Indonesia yang berdasarkan Pancasila dan Undang-Undang Dasar Negara Republik Indonesia Tahun 1945, serta rela berkorban demi menjamin kelangsungan hidup Bangsa dan Negara (Irwanto, 2013; Nainggolan, 2016).

\section{Melaksanakan Kegiatan Senam Pagi}

Pelaksanaan kegiatan senam pagi dilaksanakan setiap hari sabtu pagi sebelum memulai pembelajaran. Kegiatan ini dipimpin oleh siswa kelas IV, V, dan VI yang sudah mengikuti pelatihan singkat mengenai gerakan-gerakan dalam senam. Senam yang dipraktikkan adalah senam Riau sehat yang juga diikuti oleh siswa kelas I, III, dan IV juga guru beserta staff sekolah yang masuk pada pagi hari. Tujuan pelaksanaan kegiatan ini adalah untuk meningkatkan semangat hidup sehat dan kebugaran tubuh, dalam hal ini, kegiatan yang dilaksanakan dengan santai juga dapat memungkinkan perbauran antara siswa satu dengan yang lain tanpa membedakan satu sama lain, saling berbaris rapi, bergerak dan saling berbagi canda tawa untuk memulai hari.

Kegiatan rutin yang diwujudkan tersebut merupakan bentuk usaha dari mengenal siswa agar dapat berlatih untuk selalu tertib dan patuh pada peraturan, bertanggung jawab terhadap tugas yang diberikan, menjaga kebersihan lingkungan, dan melatih keberanian (Muthoharoh et al., 2013). Kegiatan senam pagi juga merupakan bagian dari kegiatan ekstrakurikuler, dengan ini siswa diharapkan dapat mengembangkan bakat, minat, kepribadian, dan kemampuannya di berbagai bidang non akademik secara maksimal (Wiliandani et al., 2016)

\section{Memperingati Hari Penting Nasional}

Banyak sekali contoh yang bisa disebutkan jika menyebut kata memperingati hari penting nasional. Hal tersebut dapat dicontohkan dengan memperingati hari ibu, hari guru, hari kesaktian Pancasila, hari anak dunia, hari libur keagamaan (Islam: hari raya idul fitri, hari raya idul adha, maulid Nabi Muhammad SAW, memperingati bulan muharam, dan lain sebagainya. Sedangkan untuk agama Kristen: Natal, Kenaikan Isa Almasih, dan lain sebagainya).

Pelaksanaan kegiatan memperingati hari nasional secara umum dapat berupa pelaksanaan upacara bendera pada hari-hari tertentu selain hari senin, memperingati kemerdekaan 17 Agustus, hari guru, kesaktian Pancasila, peringatan hari besar umat beragama, dan hari kartini. Memperingati hari nasional juga dilakukan dengan melakukan lomba seperti panjat pinang, lomba makan kerupuk, masukkan paku ke dalam botol, lomba sepak bola, dan lain sebagainya untuk memeriahkan hari nasional tersebut. Kemudian untuk memperingati hari nasional berkaitan keagamaan, sekolah melakukan kegiatan perayaan maulid nabi, isra' mi'raj, pesantren kilat saat bulan puasa, dan peringatan hari penting keagamaan lainnya. Tujuan pelaksanaan kegiatan tersebut adalah untuk memupuk jiwa nasionalisme di seluruh elemen sekolah, memupuk rasa persatuan dan kesatuan 
diantara siswa, guru, dan staf sekolah. Kegiatan ini dilaksanakan berdasarkan dana yang dikeluarkan oleh sekolah untuk membuat hadiah bagi yang peserta yang beruntung dan menang.

\section{Pembelajaran di Kelas}

Pembelajaran di kelas merupakan salah satu hal penting yang turut menunjang dalam proses penguatan nilai-nilai yang terkandung dalam Pancasila yang disalurkan kepada peserta didik. Pembelajaran di sekolah dasar pada umumnya menggunakan sistem tematik, artinya pembelajaran tersebut saling terhubung satu sama lainnya tergantung pada tema yang diangkat. Melalui pembelajaran di kelas ini, siswa dapat belajar teori sekaligus praktik yang terkait dengan berbagai ilmu pengetahuan.

Jumlah keseluruhan siswa di MIN 01 Tembilahan berjumlah 995 Orang, dengan siswa yang berada di kelas I, II, dan III berjumlah 456 orang dan 539 orang pada kelas IV, V, dan VI. Sistem pembelajaran di MIN 01 Indragiri Hilir dilaksanakan dengan membagi mejadi dua bagian. Bagian pertama pada pagisiang hari di isi oleh siswa kelas I, II, dan III. Siswa kelas I melakukan proses pembelajaran dari pukul 07.00 WIB sampai dengan pukul 10.00 WIB. Sedangkan bagi siswa kelas II dan III, dari pukul 07.0012.00 WIB. Kemudian untuk bagian kedua dilakukan oleh kelas IV, V, dan VI. Dilaksanakan pada siang hari, yaitu pukul 13.00-17.00 WIB. Pembagian proses pembelajaran tersebut dibagi menjadi dua karena keterbatasan lahan untuk membuat kelas tambahan, sehingga untuk mengatasi itu, sekolah mengambil kebijakan untuk setiap angkatan hanya terdiri dari 3 kelas I, A, B, dan C. Sedangkan kelas II-VI terdiri dari kurang lebih masing-masing dua kelas tiap angkatannya.

Proses pembelajaran yang dilakukan guru bukan hanya sekadar memberikan pengetahuan semata, melainkan juga terdapat beberapa proses tambahan yang membuat siswa terlibat aktif dalam pembelajaran. seperti keteladanan, contoh baik, dan lain sebagainya sebagai upaya dan tindakan untuk penguatan nilai keadilan, agar terhindar dari pendistribusian pendidikan yang tidak merata, Maka perlu dilakukan menanamkan nilai keadilan sesuai nilai-nilai Pancasila sejak dini. Penguatan nilai-nilai Pancasila juga dapat dilakukan oleh guru melalui pembelajaran PPKn pada setiap kelas yang ada di sekolah.

Pendidikan kewarganegaraan merupakan ilmu pengetahuan yang mengembangkan nilai-nilai luhur bangsa yang bersumber pada kebudayaan bangsa Indonesia yang diharapkan dapat diwujudkan dalam bentuk perilaku dalam kehidupan sehari-hari, peserta didik baik sebagai individu maupun sebagai anggota masyarakat. Dengan adanya PPKn, pembelajaran dapat berjalan sekaligus. Artinya, PPKn disamping memberikan ilmu tentang moral dan nilai-nilai kebaikan, PPKn juga dapat menjadi wahana dalam melestarikan nilai-nilai yang terkandung dalam Pancasila dan UUD 1945 secara dinamis dan terbuka (Suharyanto, 2013). Selain PPKn sebagai pembelajaran yang mengajarkan mengenai moral dan nilai-nilai terkait Pancasila. Mata pelajaran yang rurut ambil bagian dalam mengajarkan akhlak adalah pelajaran agama yang bersumber dari Al-quran dan hadis.

Berdasarkan keseluruhan kegiatan yang telah dipaparkan tersebut, penguatan nilai-nilai Pancasila dalam rangka menguatkan nilai-nilai Pancasila di MIN 01 Indragiri Hilir secara keseluruhan sudah melibatkan seluruh elemen warga sekolah dalam setiap kegiatan yang telah dibuat oleh pihak sekolah. Hal tersebut sesuai dengan apa yang diharapkan dari partisipasi atau keikutsertaan seseorang atau sekelompok anggota masyarakat dalam suatu kegiatan (Mardikanto, 2010). Hal tersebut juga membuktikan bahwa paradigma sistematis di dalam budaya sekolah dan pembelajaran yang sudah meliputi tiga domain, yakni domain akademis, domain kurikuler dan domain sosial kultural. Domain akademis tersebut meliputi berbagai pemikiran yang berkembang di lingkungan komunitas keilmuan. Kemudian domain kurikuler merupakan konsep praksis atau keterlaksanaan dari pendidikan kewarganegaraan yang terjadi di dalam dunia pendidikan formal juga non formal. 
Sedangkan domain sosial kultural merupakan ketergabungan dari konsep dan praksis yang ada di lingkungan masyarakat.

Merujuk pada hasil tersebut juga dapat diketahui bahwa perwujudan dari penguatan nilai-nilai Pancasila di MIN 01 Indragiri Hilir telah termasuk dalam domain akademis (phsyco-paedagogial development) yang melibatkan seluruh elemen sekolah dalam mengupayakan keberhasilan program dan kegiatan yang dilaksanakan untuk mewujudkan nilai-nilai Pancasila dalam kehidupan siswa agar lebih baik ke depannya. Dalam hal ini, Sekolah juga sudah berupaya dengan maksimal untuk menguatkan nilai-nilai Pancasila dengan melaksanakan berbagai program dan kegiatan positif untuk mengubah dan mewujudkan perilaku siswa yang lebih baik ke depannya berdasarkan Pancasila. Lancarnya kegiatan yang dilaksanakan di sekolah tersebut tidak lepas dari adanya beberapa kendala yang dihadapi oleh sekolah, diantara adalah lahan bangunan sekolah yang terbatas, sehingga untuk melaksanakan beberapa kegiatan yang membutuhkan ruang lebih, sekolah kesulitan untuk melakukannya.

Hal lain yang menjadi kendala dalam pelaksanaan upaya penguatan nilai-nilai Pancasila adalah sumber daya guru yang memang menguasai beberapa ekstrakurikuler juga terbatas, sekolah MIN 01 Indragiri Hilir memang memiliki lebih dari 70 pendidik, yang meliputi guru kelas, wali kelas, staf dan karyawan, serta staff kebersihan. Namun untuk tenaga ahli yang bisa pada ekstrakurikuler seperti tari, teater dan sebagainya masih terbatas. Sehingga pihak sekolah harus mengeluarkan biaya tambahan untuk menyiapkan tenaga ahli di bidang ekstrakurikuler tersebut.

Masalah lain yang muncul adalah fasilitas media dan alat peraga yang masih kurang untuk melaksanakan proses pembelajaran. Pada era disrupsi ataupun hambatan dan tantangan saat ini, peran dari media dan fasilitas yang mutakhir seperti komputer, tab, proyektor, dan lain-lain merupakan hal sangat penting untuk menunjang proses pembelajaran tersebut. Namun hal tersebut belum dimiliki sekolah, sehingga diperlukan adanya keterlibatan pemerintah dalam hal ini kementerian pendidikan untuk turut serta dalam memberikan daya dan upaya, baik uang maupun fasilitas langsung untuk mengatasi permasalahan tersebut. Walaupun sekolah tersebut mengalami keterbatasan, namun tetap melakukan rekayasa sosial untuk mengatasi masalah sosial yang muncul karena adanya ketaksesuaian antara apa yang seharusnya (das sollen) dengan apa yang menjadi kenyataan (das sein). Dalam penelitian ini rekayasa sosial yang sudah dijabarkan dengan mengidentifikasikan beberapa indikator yang meliputi sebab perubahan (cause of change), pelaku yang terlibat dalam perubahan (agent of change), sasaran perubahan (target of change), saluran perubahan (channel of change), dan strategi yang digunakan untuk melakukan perubahan (strategy of change).

\section{Simpulan}

Penguatan nilai-nilai Pancasila di MIN 01 Indragiri Hilir secara keseluruhan dilaksanakan dengan jalur sosialisasi Pancasila melalui pengembangan sosial budaya yang dilakukan dengan melaksanakan upacara bendera, melaksanakan salat berjamaah, melaksanakan kegiatan gotong-royong, pemilihan ketua kelas, melaksanakan pembelajaran di kelas, melaksanakan kegiatan senam pagi, memperingati hari penting nasional, melaksanakan kegiatan Pramuka, dan melaksanakan kegiatan gotong-royong. Kemudian kendala yang dihadapi dalam upaya penguatan nilai-nilai Pancasila di MIN 01 Indragiri Hilir meliputi kendala keterbatasan lahan, kebutuhan akan alat dan media yang terbatas, dan tenaga pendidik yang sesuai kegiatan yang dikembangkan masih kurang.

Secara keseluruhan penguatan nilai-nilai Pancasila di MIN 01 Indragiri hilir terdapat perubahan sikap dari anti sosial, egoism menjadi lebih disiplin, siswa memiliki sikap peduli sosial, sadar akan menjaga dan melestarikan lingkungan, serta dapat menjaga keseimbangan diri dari masuknya era disrupsi di Indonesia saat ini. Penguatan nilai-nilai Pancasila di MIN 01 Indragiri Hilir ini secara 
keseluruhan juga dapat mengubah perilaku siswa menjadi lebih empati, bersikap peduli sosial, memiliki disiplin tinggi, dan peduli akan lingkungan sekitar merupakan hal yang perlu dipelihara dan diteruskan adalah kesadaran dan kepedulian akan sesama. Oleh karena itu, diperlukan keterlibatan seluruh elemen baik sekolah maupun negara dalam upaya penguatan nilai-nilai Pancasila di MIN 01 Indragiri Hilir agar dapat meningkatkan kepedulian siswa akan lingkungan dan sikap sosial peserta didik dan dapat mewujudkan generasi emas yang berprestasi di masa yang akan datang.

\section{Referensi}

Ali, S. M., Rostam, K., \& Awang, A. H. (2015). School landscape environments in assisting the learning process and in appreciating the natural environment. Procedia - Social and Behavioral Sciences, 202(December 2014), 189-198. https://doi.org/10.1016/j.sbspro.2015.08.222

Amedie, J. (2015). The impact of social media on society. In Advanced Writing: Pop Culture Intersections (Vol. 2).

Arpannudin, I., \& Aulia, S. S. (2020). Citizenship and democracy: How young citizen behave democratically in digital age. Advances in Social Science, Education and Humanities Research, 418(Acec 2019), 391-395. https://doi.org/10.2991/assehr.k.200320.074

Budimansyah, D. (2010). Penguatan pendidikan kewarganegaraan untuk membangun karakter bangsa. Widya Aksara.

Creswell, J. W. (2014). Research design qualitative, quantitative, and mixed method approaches. SAGE Publication. Inc.

Effendi, T. N. (2013). Budaya gotong royong masyarakat dalam perubahan sosial saat ini. Jurnal Pemikiran Sosiologi, 2(1), 1-18. https://doi.org/10.22146/jps.v2i1.23403

Goh, D. P. S., \& van der Veer, P. (2016). Introduction: The sacred and the urban in Asia. International Sociology, 31(4), 367-374. https://doi.org/10.1177/0268580916643088

Hakam, K. A. (2011). Pengembangan model pembudayaan nilai-moral dalam pendidikan dasar di indonesia: Studi kasus di Sekolah Dasar NegeriBndungrejosari 1 Kota Malang, Jawa Timur. Sosiohumanika, 4(2), 159-184. https://doi.org/https://doi.org/10.2121/sosiohumanika.v4i2.445

Harto, K. (2018). Tantangan dosen PTKI di era industri 4.0. Jurnal Tatsqif, 16(1), 1-15. https://doi.org/10.20414/jtq.v16i1.159

Irwanto, A. C. \& J. (2013). Peranan kegiatan ekstrakurikuler pramuka dalam membentuk kedisiplinan siswa di SMP Negeri 1 Sugio Kabupaten Lamongan. Jurnal Kajian Moral Dan Kewarganegaraan, 3(1), 549-563.

Kus, Z. (2015). Participation status of primary school students. Procedia-Social and Behavioral Sciences, 177(July 2014), 190-196. https://doi.org/10.1016/j.sbspro.2015.02.381

Kusdiantini, V. (2018). Mengembangkan sumber daya manusia yang berkualitas di era disrupsi. http://news.unika.ac.id/2018/04/mengembangkan-sumber-daya-manusia-yang-berkualitas-di-eradisrupsi/

Kuzhanova, M. B., Svechnikova, N. V., Akhmetzyanova, G. N., Kondrashova, E. N., Maksimova, N. L., \& Zakharova, Z. A. (2017). Psycho-pedagogical conditions of professional culture development of a university professor. International Electronic Journal of Mathematics Education, 12(1), 15-23.

Maemunah. (2018). Kebijakan pendidikan pada era revolusi industri 4.0. Prosiding Seminar Nasional Lembaga Penelitian Dan Pendidikan (LPP) Mandala.

http://ejournal.mandalanursa.org/index.php/Prosiding/article/view/423/408

Mardikanto, T. (2010). Komunikasi pembangunan: acuan bagi akademisi, praktisi, dan peminat komunikasi pembangunan. Sebelas Maret University Press.

Mares, M. L., Sivakumar, G., \& Stephenson, L. (2015). From meta to micro: Examining the effectiveness of educational TV. American Behavioral Scientist, 59(14), 1822-1846. 
https://doi.org/10.1177/0002764215596555

Markopoulos, E., \& Vanharanta, H. (2015). The company democracy model for the development of intellectual human capitalism for shared value. Procedia Manufacturing, 3(Ahfe), 603-610. https://doi.org/10.1016/j.promfg.2015.07.277

Muthoharoh, A. I., Tijan, \& Suprayogi. (2013). Pendidikan nasionalisme melalui pembiasaan di SD Negeri Kuningan 02 Semarang Utara. Unnes Civic Education Journal, 1(2), 1-12.

Nainggolan, N. (2016). Peranan kepramukaan dalam membina sikap nasionalisme pada gugus melati Banda Aceh. Jurnal IImiah Mahasiswa Prodi PGSD, 1(June), 88-97.

Nasihuddin, M. (2016). Pola pendidikan karakter dengan konsep spiritualisme pendidikan (studi kasus di Madrasah Ibitdaiyah Ma'arif Tempurrejo Ngawi). Dirasat: Jurnal Manajemen \& Pendidikan Islam, 1(2), 248-262.

Necula, M. I. (2014). Religious values left outside the scope of penal protection. Procedia-Social and Behavioral Sciences, 149, 634-638. https://doi.org/10.1016/j.sbspro.2014.08.240

Niron, M. D., Budiningsih, \& Pujriyanto. (2013). Rujukan integratif dalam pelaksanaan pendidikan karakter di sekolah dasar. Jurnal Kependidikan, 43(1), 19-31. https://doi.org/https://doi.org/10.21831/jk.v43i1.1955

Nursyifa, A. (2019). Transformasi pendidikan ilmu pengetahuan sosial dalam menghadapi era revolusi industri 4.0. Jurnal Pendidikan Kewarganegaraan, 6(1), 51-64. https://doi.org/10.32493/jpkn.v6i1.y2019.p51-64

Pachur, T., \& Spaar, M. (2015). Domain-specific preferences for intuition and deliberation in decision making. Journal of Applied Research in Memory and Cognition, 4(3), 303-311. https://doi.org/10.1016/j.jarmac.2015.07.006

Puspitasari, P., Djunaedi, S. A., \& Putra, H. S. A. (2012). Ritual and space structure: Pilgrimage and space use in historical urban kampung context of Luar Batang (Jakarta, Indonesia). Procedia - Social and Behavioral Sciences, 36(June 2011), 350-360. https://doi.org/10.1016/j.sbspro.2012.03.039

Revolusi Industri 4.0 dan Pentingnya Pengembangan Kualitas Sumber Daya Manusia (SDM) Indonesia Halaman all - Kompasiana.com. (n.d.). Retrieved September 30, 2020, from https://www.kompasiana.com/danielmashudi/5c2f217143322f1bad375914/revolusi-industri-4-0-danpentingnya-pengembangan-sumber-daya-manusia-indonesia?page=all

Satya, V. E. (2018). Pancasila dalam menghadapi era revolusi industri 4.0. In Pusat Penelitian Badan Keahlian DPR RI: Vol. X (Issue 09).

Subekti, H., Taufiq, M., Susilo, H., Ibrohim, I., \& Suwono, H. (2018). Mengembangkan literasi informasi melalui belajar berbasis kehidupan terintegrasi stem untuk menyiapkan calon guru sains dalam menghadapi era revolusi industri 4.0: review literatur. Education and Human Development Journal, 3(1), 81-90. https://doi.org/10.33086/ehdj.v3i1.90

Sugiyono. (2012). Metode penelitian kuantitatif kualitatif dan R\&D. Alfabeta.

Suharyanto, A. (2013). Peranan pendidikan kewarganegaraan dalam membina sikap toleransi antar siswa. Jurnal Ilmu Pemerintahan Dan Sosial Politik 1, 1(2), 192-203.

Suwardana, H. (2018). Revolusi industri 4.0 berbasis revolusi mental. JATI UNIK, 1(2), 109-118. https://doi.org/http://dx.doi.org/10.30737/jatiunik.v1i2.117

Trisiana, A., Sugiaryo, \& Rispantyo. (2019). Implementasi pendidikan karakter dalam pendidikan kewarganegaraan sebagai inovasi pengembangan di era media digital dan revolusi industri 4.0. Jurnal Global Citizen: Jurnal IImiah Kajian Pendidikan Kewarganegaraan, 7(1), 84-98. https://doi.org/http://dx.doi.org/10.33061/jgz.v7i1.3059

Triyanto, T., \& Fadhilah, N. (2018). Penguatan nilai-nilai Pancasila di sekolah dasar. Jurnal Civics: Media Kajian 
Kewarganegaraan, 15(2), 161-169. https://doi.org/10.21831/jc.v15i2.20709

Vassil, K., \& Weber, T. (2011). A bottleneck model of e-voting: Why technology fails to boost turnout. New Media and Society, 13(8), 1336-1354. https://doi.org/10.1177/1461444811405807

Wiliandani, A. M., Wiyono, B. B., \& Sobri, A. Y. (2016). Implementasi pendidikan karakter dalam pembelajaran di sekolah dasar. Jurnal Pendidikan Humaniora, 4(3), 132-142. https://doi.org/10.17977/JPH.V4I3.8214 


\section{Lampiran}

Gambar 1. Pelaksanaan kegiatan upacara bendera setiap hari senin

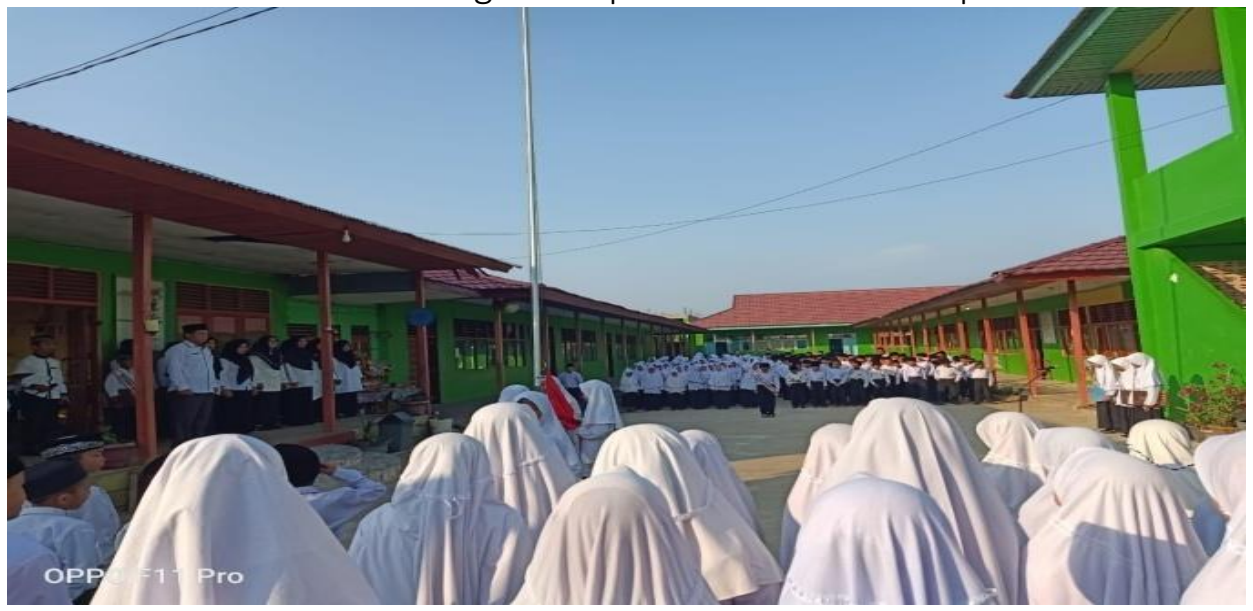

Gambar 2. Pelaksanaan kegiatan pelatihan pramuka

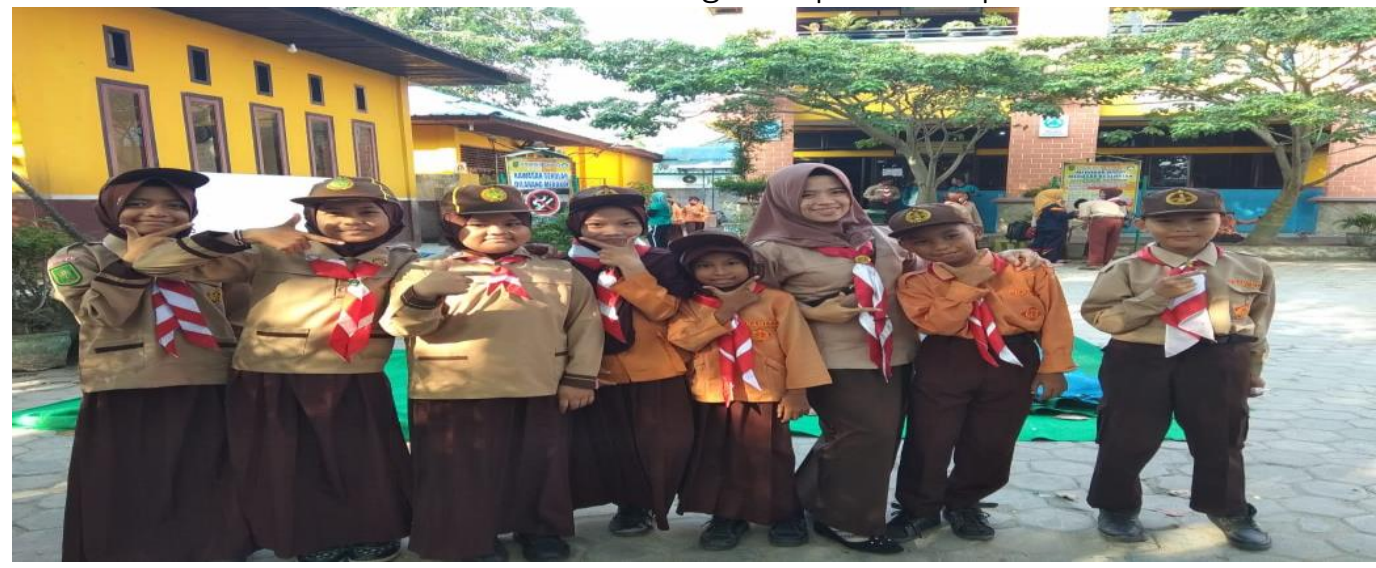

Gambar 3. Pelaksanaan upacara pada hari-hari besar nasional.

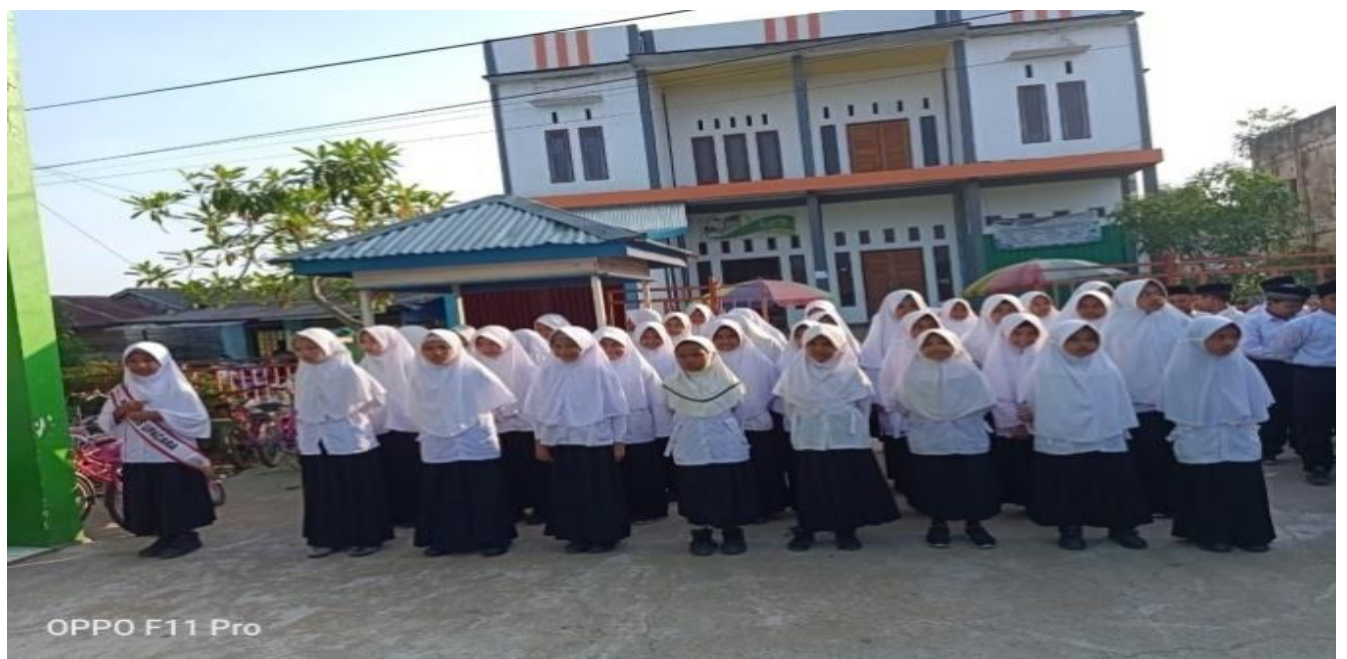


Gambar 4. Pelaksanaan kegiatan yasinan setiap hari jum'at.

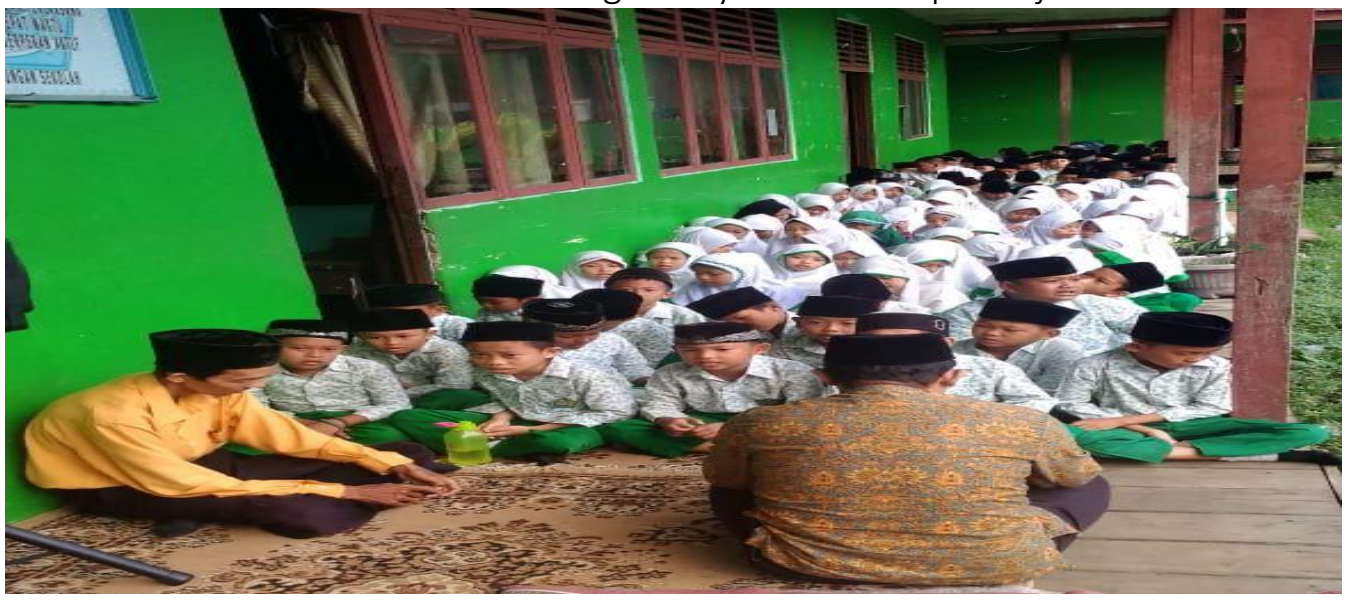

Gambar 5. Lingkungan sekolah MIN 01 Indragiri Hilir yang Bersih dan indah

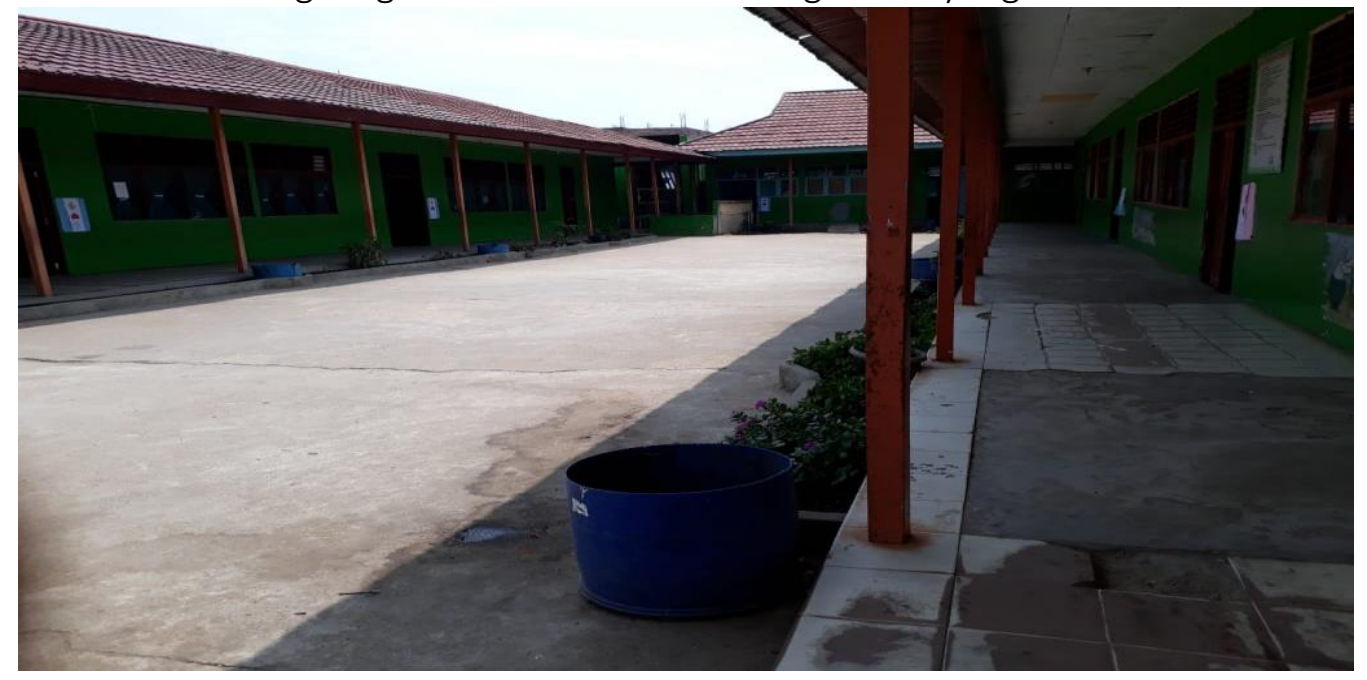

